\title{
Purchasing Power Parity: Evidence from Selected High and Low Inflation Countries
}

\author{
Yusuf Haji-Othman $^{1} \&$ Sani Yahaya ${ }^{1}$ \\ ${ }^{1}$ Kulliyyah of Muamalat Kolej University Insaniah (KUIN) Lebuhraya Sultanah Bahiyah, Alor Setar, Kedah \\ Darul Aman, Malaysia \\ Correspondence: Sani Yahaya, No. 141, Lorong Insaniah 2/11, Taman Insaniah, 09300 Kuala Ketil, Kedah, \\ Malaysia. E-mail: saniytm@yahoo.com
}

Received: October 30, 2014

Accepted: November 24, 2014

Online Published: December 25, 2014

doi:10.5539/ibr.v8n1p50

URL: http://dx.doi.org/10.5539/ibr.v8n1p50

\begin{abstract}
This paper reexamines the long run relationship between nominal bilateral exchange rate and the price index ratio for high and low inflation countries using time series analysis techniques. Tests for non-stationarity were carried out before cointegration analysis was conducted. Theoretically, Purchasing Power Parity (PPP) should receive empirical support in the case of high-inflation countries. This is because PPP is a monetary phenomenon and monetary factors tend to overshadow real factors in high-inflation countries. The findings show that high inflation countries such as Sierra Leone and Mexico support the Theory of Purchasing Power Parity (PPP). In the case of low inflation countries, none of the countries provides evidence supporting theory of PPP.
\end{abstract}

Keywords: cointegration, high inflation countries, low inflation countries, Purchasing Power Parity (PPP)

\section{Introduction}

The purpose of this paper is to reexamine long run equilibrium in exchange rate and to establish empirical evidence on the possible long run relationship between nominal bilateral exchange rate and price index ratio for selected high and low inflation countries. Since time series data are used, the possibilities of spurious regression relationships among variables exist unless an appropriate statistical test of long run relationship takes into account important characteristics of time series data. Specifically, the DF and ADF test are used to check whether all variables are non-stationary followed by the cointegration analysis.

This study can be justified as follows: i) it differs from most of earlier studies, as it focuses on sample from the high and low inflation countries, ii) By adopting the cointegration method, the problem of spurious regression is avoided as only non stationary variables will be proceeded for the estimation. iii) The findings of this study provide the empirical evidence that for high inflation countries such as Sierra Leone and Mexico the theory of PPP do hold and for low inflation countries, it does not hold.

\section{Literature Review}

There are voluminous literatures on purchasing power parity (PPP). Most studies show only weak evidence supporting PPP or no evidence at all. Only a small number of studies provide evidence supporting PPP.There are various methods of testing PPP. Since Engle and Granger (1987) introduced a procedure to determine whether variable is cointegrated, numerous studies have used the procedure to determine if exchange rate has a long run relationship with PPP.Baillie and Selover (1987), McNown and Wallace (1990) and Gan (1991) use Engel and Granger procedure to test PPP. In the case of PPP, $X_{t}$ is nominal exchange rate and $Y_{t}$ is purchasing power. If the two variables are cointegrated, then PPP holds. Bahmani (1993) also uses Engel and Granger procedure, but he tests the law of one price where $\mathrm{X}_{\mathrm{t}}$ is domestic price level, while $\mathrm{Y}_{\mathrm{t}}$ is the product of nominal exchange rate and foreign price level.

Baghestani (1997), Edison, Gagnon and Melick (1997), Fritsche and Wallace (1997), Phylaktis (1992), and Zhou and Mahdavi (1994) use Engel and Granger method or ADF test to determine nonstationarity of nominal exchange rate and purchasing power. After it is determined that it is nonstationary, Johansen procedure is used to determine whether they are cointegrated. If they are, then PPP holds. Bahmani (1995) and Gan (1991) use Dickey-Fuller, Augmented Dickey-Fuller or Perron tests to determine stationarity of real exchange rate. If the real exchange rate is stationary, then PPP holds. Zhou (1997) uses Zivot and Andrews procedure to determine 
nonstationarity of variables that contain structural break. Johansen procedure is used to determine if nominal exchange rate and purchasing power is cointegrated. If they are cointegrated, then PPP holds.

There are mixed evidence on PPP. Baghestani (1997), Bahmani (1993) (using black market exchange rate), McNown and Wallace (1990) (during fixed exchange rate period), Phylaktis (1992), Zhou (1997), Zhou and Mahdavi (1994) provide moderate or strong support for PPP.

On the other hand, Bahmani (1993), Bahmani (1995), Baillie and Selover (1997), Gan (1991), Edison, Gagnon and Melick (1997), Fitsche and Wallace (1997), and McNown and Wallace (1990) provide lack of support for PPP.

It can be seen that since the birth of PPP as a theory after World War I until 1986, PPP had not been a fertile area of research. Only after the development of cointegration analysis, PPP became a fertile area of research. Since cointegration enables researchers to examine a long run relationship among variables, researchers have taken advantage to apply the technique to test whether there is a long run relationship between exchange rates and purchasing powers (PPP equation). In short, studies on PPP were quite dull before the advent of cointegration. But since Engel and Granger (1987) procedure, PPP has become a fertile area of research. Evidence in favor of PPP is quite weak despite voluminous studies on the topic.

\section{Theoretical Framework}

In an influential article "Money and foreign exchange rate after 1914", Cassel (1922) proposed the use of purchasing powers from 1914 as a measure of exchange rate, therefore, maintaining the purchasing power parity (Rogoff, 1996). Therefore, Cassel not only proposes a formula for calculating equilibrium exchange rate, but also proposes a solution to maintain gold parity.

Cassel defines purchasing power parity as the parity between exchange rate and purchasing power. If domestic price increases, exchange rate should accordingly increase; other things remain unchanged, and vice versa. In the long run equilibrium, exchange rate cannot deviate very much from the purchasing power, provided that there is no trade restriction (Cassel, 1918, p. 413).

Cassel puts forward a formula for calculating the equilibrium exchange rate. He proposes that the relative purchasing power of money as measured by purchasing power between any two countries is the primary factor affecting the exchange rate, though not the only factor. He assumes people hold money for what it can buy, which is measured by purchasing power of money. In that sense, money is neutral. Secondly, arbitrage activities will ensure that the exchange rate cannot deviate from this equilibrium in the long run.

So, it must be emphasized that what Cassel proposes is actually long run equilibrium. In a later article, Cassel again reiterates that exchange rate should equal purchasing power, provided that there is no trade restriction and the relative inflation rate does not change. If the inflation rate changes, then the exchange rate should change accordingly. The new exchange rate should equal the old rate times "...the degrees of inflation of both countries" (Cassel, 1921, pp. 36-37).

According to Cassel, if equilibrium is known, then exchange rate should adjust to the change in the relative inflation rate between the two countries (Cassel, 1922, p. 175). In its simplest form, PPP asserts that the movement in exchange rate is determined by movement in the relative purchasing power of money in the two countries, assuming away transportation costs and trade restrictions. In notation:

$$
R=P / P^{*}
$$

Where $\mathrm{R}$ is nominal bilateral exchange rate, measured as units of domestic currency per units of foreign currency, $\mathrm{P}$ is price level, and asterisk represents foreign quantity.

$\mathrm{PPP}$ is said to be in long run equilibrium if $\mathrm{R}=\mathrm{P} / \mathrm{P}^{*}$. If $\mathrm{R}$ is less than $\mathrm{P} / \mathrm{P}^{*}$, then it is cheaper to buy the good in the foreign country and sell it in the domestic country. This would increase demand for foreign currency relative to domestic currency, which in turn would put upward pressure on the nominal exchange rate until they are at parity and vice versa.

Theoretically, PPP should receive empirical support in the case of high-inflation countries. This is because PPP is a monetary phenomenon and monetary factors tend to overshadow real factors in high-inflation countries.

In empirical studies, even this proposition does not receive empirical support. So, PPP does not receive empirical support in all cases of high-inflation countries. If we choose five high-inflation countries as a sample, we do not expect that all of the countries would support the theory of PPP. The weak empirical support of PPP does not necessarily mean that PPP proposition is false. Rather, it points to the assumptions that cannot be met in the real world and therefore, make limitations of PPP; which include the presence of transportation costs and trade 
restrictions, the existence of nontraded goods in the price index, the existence of controlled items in the calculation of price index, and the unequal weighting put on items included in the price index. Besides that, some countries might not take advantage of the disparities between exchange rate and purchasing power of money. Therefore, it is expected that PPP would receive a weak support.

This study hypothesizes that:

H1: Purchasing Power Parity would receive empirical support in the case of high inflation countries.

H2: Purchasing Power Parity would not receive empirical support in the case of low inflation countries.

\section{Methodology}

This study uses Engel and Granger (1987) procedure to examine long-run equilibrium exchange rate, short run dynamics and speed of adjustment and direction of causality between exchange rate and PPP.

According to Engel and Granger (1987), any economic time series can follow a random walk path and yet any pair of the series can be expected to move together over time. If that is true, then the two series are said to be cointegrated. In other words, even though the individual series is nonstationary, if the distance between the two series is found to be stationary, then the two series is said to be in long run equilibrium.

More formally, two economic variables, $X_{t}$ and $Y_{t}$, are cointegrated if $X_{t}$ and $Y_{t}$ areintegrated of the same order, d, and a linear combination between the two variables such as $Z_{t}=X_{t}-\alpha Y_{t}$ is integrated of order $(d-b)$ where $b>0$.

If the two series are integrated of different orders, then it can be proven that they will wander farther and farther apart from each other over time. If they are integrated of the same order, $d$, but the linear combination is integrated of the same order, $\mathrm{d}$, it can be proven that the two series do not move together over time in the long run.

In a more general case, Engel and Granger (1987, p. 253) give this definition:“The components of the vector $x_{t}$ are said to be co-integrated of order $d, b$ denoted $x_{t} \sim C I(d, b)$ if (i) all components of $x_{t}$ are I (d): (ii) there exists a vector $\alpha(\neq 0)$ so that $\mathrm{z}_{\mathrm{t}}=\alpha$ ' $\mathrm{x}_{\mathrm{t}} \sim \mathrm{I}(\mathrm{d}-\mathrm{b}), \mathrm{b}>0$. The vector $\alpha$ is called the co-integrated vector."

There are three important steps in the procedure:

\section{Step 1. Test the order of integration of each variable.}

The commonly used tests include using Dickey-Fuller Test (DF Test) and Augmented Dickey-Fuller Test (ADF Test). If they are cointegrated of different orders, then it is concluded that the two series are not cointegrated. If they are integrated of the same order, 0 , then standard time series method cannot be applied. If they are integrated of the same order, $d$, where $d<0$, then proceed with step two.

\section{Step 2. Test the order of integration of the linear combination between the variables.}

As an approximation, residual from OLS is used. ADF Test is applied to the autoregression of the residuals:

$$
\Delta e_{t}=a_{1} e_{t-1}+\varepsilon_{t}
$$

If it is integrated of any order less than $\mathrm{d}$, then it is concluded that cointegration exists among the variables.

\section{Step 3. Test the short run dynamics and causality using error-correction model of the form:}

$$
\begin{aligned}
& \Delta X_{t}=\alpha_{1}+\alpha_{X}\left(X_{t-1}-\beta_{1} Y_{t-1}\right)+\sum \alpha_{11}(i) \Delta X_{t-i}+\sum \alpha_{12}(i) \Delta Y_{t-i}+\varepsilon_{X t} \\
& \Delta Y_{t}=\alpha_{2}+\alpha_{Y}\left(X_{t-1}-\beta_{1} Y_{t-1}\right)+\sum \alpha_{21}(i) \Delta X_{t-i}+\sum \alpha_{22}(i) \Delta Y_{t-i}+\varepsilon_{Y t}
\end{aligned}
$$

Where $\beta_{1}=$ parameter of cointegrating vector, $\varepsilon_{\mathrm{Xt}}$ and $\varepsilon_{\mathrm{Yt}}=$ random errors, and all $\alpha$ 's are parameters.

Equation (2) and (3) can be written as equation (4) and (5), respectively:

$$
\begin{aligned}
\Delta \mathrm{X}_{\mathrm{t}} & =\alpha_{1}+\alpha_{\mathrm{X}}\left(\varepsilon_{\mathrm{t}-1}\right)+\sum \alpha_{11}(\mathrm{i}) \Delta \mathrm{X}_{\mathrm{t}-\mathrm{i}}+\sum \alpha_{12}(\mathrm{i}) \Delta \mathrm{Y}_{\mathrm{t}-\mathrm{i}}+\varepsilon_{\mathrm{Xt}} \\
\Delta \mathrm{Y}_{\mathrm{t}} & =\alpha_{2}+\alpha_{\mathrm{Y}}\left(\varepsilon_{\mathrm{t}-1}\right)+\sum \alpha_{21}(\mathrm{i}) \Delta \mathrm{X}_{\mathrm{t}-\mathrm{i}}+\sum \alpha_{22}(\mathrm{i}) \Delta \mathrm{Y}_{\mathrm{t}-\mathrm{i}}+\varepsilon_{\mathrm{Yt}}
\end{aligned}
$$

In equation (4), if $\alpha_{\mathrm{X}}$ is significant and/or $\alpha_{12}$ (i)'s are jointly significant, then the $\mathrm{Y}$ is said to cause $\mathrm{X}$. Therefore, the error-correction model allows for the finding that $\mathrm{Y}$ Granger causes $\mathrm{X}$, as long as the error-correction term carries a significant coefficient even if the $\alpha_{12}$ (ii)'s are not jointly significant. However, if $\mathrm{X}$ and $\mathrm{Y}$ are not cointegrated, then the error-correction terms are dropped from the two equations and the simple Granger causality test is carried out.

\section{Data}

In this study, secondary data is used and it is based on quarterly data for the period of 1973-1996. Variables that 
are chosen are nominal bilateral exchange rate (r) and price level (p), which are gathered and verified from various sources such as International Financial Statistics (IFS) on CD-ROM and also OECD main economic indicators. All variables are in logarithm form. Exchange rates are quarterly averages in terms of U.S dollars while price indices are measured by consumer price index (CPI).

This study selects one sample on high-inflation countries vs. one sample on low-inflation countries. High inflation countries are defined as countries having average inflation rate higher than 25 per cent in the long run. On the other hand, low-inflation countries are defined as countries having inflation rate lower than 10 per cent. In between are middle inflation countries. The sample of high and low-inflation countries is shown in table 1.

Table 1. Sample of high and low-inflation countries*

\begin{tabular}{lccc}
\hline High-inflation Countries & Inflation Rate (\%) & Low-inflation Countries & Inflation Rate (\%) \\
\hline Chile & 80.61 & Malaysia & 4.69 \\
Uruguay & 62.66 & Singapore & 4.18 \\
Turkey & 52.04 & Netherlands & 4.10 \\
Sierra Leone & 45.92 & Switzerland & 3.66 \\
Suriname & 43.72 & & \\
Mexico & 40.54 & &
\end{tabular}

*Quarterly data is used for all countries. For Chile and Uruguay, data run from 1976:1 to 1998:1. The first quarter of 1976 is selected as the starting period because data on Chile's CPI is not available for any period before that. For Turkey, Suriname and Mexico, the period is 1973:1 to 1998:1. For Sierra Leone, data covers period 1973:1 to 1997:4.

\section{Results}

\subsection{The Case of High Inflation Countries}

The Dickey-Fuller (DF) and an Augmented Dickey-Fuller (ADF) test are used in this study to test for integration levels. These are both test and rely on rejecting the hypothesis that the series is a random walk in favor of stationarity. By using Eviews, the DF and ADF test for unit roots for all selected countries are shown in Table 2. Since data is quarterly, lag length of 8 is chosen at the beginning. Then, the length is shortened until all coefficients are statistically significant.

Table 2 indicates that $\log (\mathrm{R})$ and $\log \left(\mathrm{P} / \mathrm{P}_{\mathrm{US}}\right)$ for Chile, Uruguay and Suriname are integrated of different orders. This leads us to conclude that there is no cointegration in the two series for these three countries. However, the two series are integrated of the same order for Mexico, Sierra Leone and Turkey, i.e. all series are I(1). Therefore, the next step is carried out for these series.

As an approximation, residual from OLS, $e_{t}=\log (R)_{t}-\beta \log (p)_{t}$ is used, where $p=P / P_{U S}$.

ADF Test is applied to the auto regression of the residuals:

$$
\Delta e_{t}=a_{1} e_{t-1}+\varepsilon_{t}
$$

Table 2. ADF test statistics

\begin{tabular}{|c|c|c|c|c|}
\hline Variables & $\mathbf{N}$ & Levels & $1^{\text {st }}$ Differences & $2^{\text {nd }}$ Differences \\
\hline \multicolumn{5}{|l|}{ Country } \\
\hline \multicolumn{5}{|l|}{ CHILE } \\
\hline \multirow[t]{2}{*}{$\Delta \log \left(\mathrm{R}_{\mathrm{Chi}}\right)$} & 89 & $-0.02(3)$ & $-0.46(0) * * *$ & \\
\hline & & $(-1.58)$ & $(-5.28)$ & \\
\hline \multirow[t]{2}{*}{$\Delta \log \left(\mathrm{P}_{\mathrm{Chi}} / \mathrm{P}_{\mathrm{US}}\right)$} & 89 & $-0.27(1)^{* * *}$ & & \\
\hline & & $(-5.22)$ & & \\
\hline
\end{tabular}




\section{URUGUAY}

$\Delta \log \left(\mathrm{R}_{\mathrm{Uru}}\right)$

$\Delta \log \left(\mathrm{P}_{\mathrm{Chi}} / \mathrm{P}_{\mathrm{US}}\right)$

89

$\Delta \log \left(\mathrm{R}_{\mathrm{Tur}}\right)$

$\Delta \log \left(\mathrm{P}_{\text {Tur }} / \mathrm{P}_{\mathrm{US}}\right)$

SURINAME

$\Delta \log \left(\mathrm{R}_{\text {Sur }}\right)$

$\Delta \log \left(\mathrm{P}_{\text {Sur }} / \mathrm{P}_{\mathrm{US}}\right)$

$\Delta \log \left(\mathrm{P}_{\text {SLeon }} / \mathrm{P}_{\mathrm{US}}\right)$

$\Delta \log \left(\mathrm{R}_{\text {SLeon }}\right)$

MEXICO

$\Delta \log \left(\mathrm{R}_{\mathrm{Mex}}\right)$

$\Delta \log \left(\mathrm{P}_{\mathrm{Mex}} / \mathrm{P}_{\mathrm{US}}\right)$
101

101

101

97

97

89

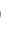

101

101

101
$-0.91(0)^{* * * *}$

$(-8.42)$

-0.08 (1)

(-1.83)

-0.04 (0)

$(-1.85)$

-0.01 (1)

(-0.60)

-0.04 (1)

(1.38)

-0.01 (1)

(-1.71)

-0.05 (1)

$(-2.07)$

$-0.04(0)$

$(-2.21)$

-0.03 (3)

(-2.16)

$-0.09$

(-2.01)
$-1.52(1)^{* * * *}$

$(-8.92)$

$-0.87(0) * * *$

(-8.71)

$-0.85(0) * * *$

$(-8.53)$

$-0.89(0) * * *$

(-8.91)

-0.19 (0)

$(-3.11)$

$-1.12(0) * * *$

$(-11.14)$

The subscripts identify the country: Chi is Chile, Uru is Uruguay, Tur is Turkey, SLeon is Sierra Leone, Sur is Suriname, and Mex is Mexico. Figures in parentheses to the right of the coefficients are the selected lag length. Figures in parentheses below coefficients are ADF Statistics. Note: Critical Values for t-statistics from MacKinnon (1991):

\begin{tabular}{lcccc}
\hline & $\mathrm{n}$ & t-statistics (significance level) \\
\hline $\mathrm{T}$ & 89 & $-4.06(1 \%)$ & $-3.46(5 \%)$ & $-3.16(10 \%)$ \\
$\mathrm{T}$ & 97 & $-4.06(1 \%)$ & $-3.46(5 \%)$ & $-3.15(10 \%)$ \\
$\mathrm{T}$ & 101 & $-4.05(1 \%)$ & $-3.45(5 \%)$ & $-3.15(10 \%)$ \\
\hline
\end{tabular}

*** indicates that the variable is significant at $1 \%$;

** indicates that the variable is significant at $5 \%$;

*indicates that the variable is significant at $10 \%$;

$\mathrm{t}$ indicates that a constant and time trend is included in the regression.

ADF Test is carried out on the first difference and the output is shown in Table 3. 
Table 3. Estimated $\delta$ and the associated ADF test statistics for level term

\begin{tabular}{|c|c|c|c|}
\hline Variables & $\mathbf{N}$ & Levels & $1^{\text {st }}$ Differences \\
\hline \multicolumn{4}{|l|}{ Country } \\
\hline \multicolumn{4}{|l|}{ TURKEY } \\
\hline \multirow[t]{2}{*}{$\Delta \mathrm{e}_{1 \mathrm{Tur}}$} & 101 & $-0.04(0)$ & $-0.98(0) * * *$ \\
\hline & & $(-1.36)$ & $(-9.64)$ \\
\hline \multirow[t]{2}{*}{$\Delta \mathrm{e}_{2}$ Tur } & 101 & $-0.04(0)$ & $-0.98(0) * * *$ \\
\hline & & $(-1.38)$ & $(-9.64)$ \\
\hline \multicolumn{4}{|c|}{ SIERRA LEONE } \\
\hline \multirow[t]{2}{*}{$\Delta \mathrm{e}_{1 \text { SLeon }}$} & 97 & $-0.35(0) * * *$ & $-0.80(0)$ *** \\
\hline & & $(-4.44)$ & $(-7.88)$ \\
\hline \multirow[t]{2}{*}{$\Delta \mathrm{e}_{2 \text { SLeon }}$} & 97 & $-0.46(2) * * *$ & $-1.10(0) * * *$ \\
\hline & & $(-4.77)$ & $(-10.77)$ \\
\hline \multicolumn{4}{|l|}{ MEXICO } \\
\hline \multirow[t]{2}{*}{$\Delta \mathrm{e}_{1 \mathrm{Mex}}$} & 101 & $-0.39(1) * *$ & $-0.40(1) * *$ \\
\hline & & $(-3.82)$ & $(-4.02)$ \\
\hline \multirow[t]{2}{*}{$\Delta \mathrm{e}_{2 \mathrm{Mex}}$} & 101 & $-0.39(1) * *$ & $-1.67(1) * * *$ \\
\hline & & $(-3.84)$ & $(-9.86)$ \\
\hline
\end{tabular}

The subscripts identify the country: Mex is Mexico, SLeon is Sierra Leone, and Tur is Turkey. Figures in parentheses to the right of coefficients are the selected lag length. Figures in parentheses below coefficients are ADF t-statistics.

Note: Critical Values for t-statistics:

\begin{tabular}{lcccc}
\hline & $\mathrm{n}$ & \multicolumn{3}{c}{$\mathrm{t}$-statistics (significance level) } \\
\hline $\mathrm{T}$ & 97 & $-4.06(1 \%)$ & $-3.46(5 \%)$ & $-3.15(10 \%)$ \\
$\mathrm{T}$ & 101 & $-4.05(1 \%)$ & $-3.46(5 \%)$ & $-3.15(10 \%)$ \\
\hline
\end{tabular}

*** indicates that the variable is significant at $1 \%$;

** indicates that the variable is significant at $5 \%$;

*indicates that the variable is significant at $10 \%$;

$\mathrm{t}$ indicates that a constant and time trend is included in the regression.

Table 3 shows that the hypothesis of unit root for both of Mexico's residual series in levels is rejected at 5 per cent significant level. The hypothesis is also rejected for both series of Sierra Leone in levels at 1 per cent significant level. This leads us to conclude that exchange rates and purchasing powers (in logarithm forms) are cointegrated in the case of Mexico and Sierra Leone.

However, the hypothesis of unit root for both of residual series of Turkey in levels cannot be rejected. The hypothesis is rejected for both series in their first differences. This means that both series are integrated of order one, I(1). This leads us to conclude that there is no cointegration between exchange rate and purchasing power (in $\log$ form) in the case of Turkey.

\subsection{The Case of Low Inflation Countries}

Using the same method use as in the case of high inflation countries, results are shown in Table 4. 
Table 4. Estimated $\delta$ and ADF test statistics for level term

\begin{tabular}{|c|c|c|c|c|}
\hline Variables & $\mathbf{N}$ & Levels & $\mathbf{1}^{\text {st }}$ Differences & $2^{\text {nd }}$ Differences \\
\hline \multicolumn{5}{|l|}{ Country } \\
\hline \multicolumn{5}{|l|}{ MALAYSIA } \\
\hline \multirow[t]{2}{*}{$\Delta \log \left(\mathrm{R}_{\mathrm{My}}\right)$} & 100 & -0.14 & $-0.76(1) * * *$ & \\
\hline & & $(-2.53)$ & $(-4.96)$ & \\
\hline \multirow{2}{*}{$\Delta \log \left(\mathrm{P}_{\mathrm{My}} / \mathrm{P}_{\mathrm{US}}\right)$} & 100 & $-0.01(4)$ & $-0.40(3)$ & $-2.58(2) * * *$ \\
\hline & & $(-1.15)$ & $(-3.02)$ & $(-10.17)$ \\
\hline \multicolumn{5}{|l|}{ SINGAPORE } \\
\hline \multirow{2}{*}{$\Delta \log \left(\mathrm{R}_{\text {Spore }}\right)$} & 101 & $-0.08(1)$ & $-0.88(1) * * *$ & \\
\hline & & $(-2.27)$ & -6.83 & \\
\hline \multirow[t]{2}{*}{$\Delta \log \left(\mathrm{P}_{\text {Spore }} / \mathrm{P}_{\mathrm{US}}\right)$} & 101 & $-0.08(2) * *$ & & \\
\hline & & $(-3.53)$ & & \\
\hline \multicolumn{5}{|c|}{ NETHERLAND } \\
\hline \multirow[t]{2}{*}{$\Delta \log \left(\mathrm{R}_{\text {Neth }}\right)$} & 101 & $-0.07(1)$ & $-0.72(0) * * *$ & \\
\hline & & $(-2.22)$ & $(-7.43)$ & \\
\hline \multirow[t]{2}{*}{$\Delta \log \left(\mathrm{P}_{\mathrm{Neth}} / \mathrm{P}_{\mathrm{US}}\right)$} & 101 & $-0.03(2)$ & $-0.38(1) * *$ & \\
\hline & & $(-1.87)$ & $(-3.73)$ & \\
\hline \multicolumn{5}{|c|}{ SWITZERLAND } \\
\hline \multirow[t]{2}{*}{$\Delta \log \left(\mathrm{R}_{\mathrm{Swi}}\right)$} & 101 & $-0.97(0) * * *$ & & \\
\hline & & $(9.66)$ & & \\
\hline \multirow[t]{2}{*}{$\Delta \log \left(\mathrm{P}_{\mathrm{Swi}} / \mathrm{P}_{\mathrm{US}}\right)$} & 101 & $-0.02(3)$ & $-0.29(3)$ & $-2.50(2) * * *$ \\
\hline & & $(-1.82)$ & $(-3.01)$ & $(-11.24)$ \\
\hline
\end{tabular}

The subscripts identify the country: My is Malaysia, Spore is Singapore, Neth is Netherlands, and Swi is Switzerland.

Figures in parentheses to the right of coefficients are the selected lag length. Figures in parentheses below coefficients are ADF Statistics.

Note: Critical Values for t-statistics from MacKinnon (1991):

\begin{tabular}{|c|c|c|c|c|}
\hline \multirow[b]{2}{*}{$\mathrm{T}$} & \multicolumn{2}{|l|}{$\mathrm{n}$} & \multicolumn{2}{|c|}{ statistics (significance level) } \\
\hline & $100(101)$ & $-4.05(1 \%)$ & $-3.45(5 \%)$ & $-3.15(10 \%)$ \\
\hline
\end{tabular}

*** indicates that the variable is significant at $1 \%$;

** indicates that the variable is significant at $5 \%$;

*indicates that the variable is significant at $10 \%$;

$\mathrm{t}$ indicates that a constant and time trend is included in the regression.

Table 4 shows that nominal bilateral exchange rates (in log forms) and purchasing powers (in log forms) for Malaysia, Singapore and Switzerland are integrated of different orders. Therefore, it leads us to conclude that the two series are not cointegrated for Malaysia, Singapore and Switzerland. However, the two series for Netherlands are integrated of the same order, i.e. both are I(1). Therefore, the next step is carried out which is the residual based test. Results are shown in Table 5. 
Table 5. Estimated $\mathrm{a}_{1}$ and ADF test statistics

\begin{tabular}{llll}
\hline Variables & $\mathbf{N}$ & Levels & $\mathbf{1}^{\text {st }}$ Differences \\
\hline Country & & & \\
\hline NETHERLAND & \multirow{2}{*}{101} & $-0.06(1)$ & $-0.75(0) * * *$ \\
$\Delta \log \left(\mathrm{R}_{\text {Neth }}\right)$ & & $(-2.06)$ & $(-7.62)$ \\
& \multirow{2}{*}{101} & $-0.06(1)$ & $-0.7(0) * *$ \\
$\log \left(\mathrm{P}_{\text {Neth }} / \mathrm{P}_{\mathrm{US}}\right)$ & & $(-1.92)$ & $(-7.84)$ \\
& &
\end{tabular}

$\mathrm{t}$ indicates that a constant and time trend is included in the regression.

For 101 observations, the critical values and their respective significance levels are $-4.05(1 \%),-3.46(5 \%)$, and $-3.15(10 \%)$, respectively. Therefore, for level term of the residuals, the hypothesis of a unit root cannot be rejected. The hypothesis is rejected in the case of first difference. Therefore, it is concluded that the residuals are I(1). Therefore, it leads us to conclude that there is no cointegration between nominal bilateral exchange rate and purchasing power in the case of Netherlands.

\section{Conclusion}

Based on the findings, one can observes that there exists a long run relationship between exchange rate and purchasing power. However, because of limitation such as the presence of trade restrictions and transportation costs, the empirical evidence supporting the theory of purchasing power parity is rather weak. Only two out of five high inflation countries provide evidence supporting the theory of PPP. None of the low inflation countries give empirical evidence supporting the theory of PPP.

From the results, we can conclude that the higher a country's inflation rate, the more likely PPP would receive empirical evidence. For low inflation country such as Malaysia, PPP is not considered to a good benchmark to determine exchange rate.

\section{References}

Abuaf, N., \& Jorian, P. (1990). Purchasing power parity in the long run. Journal of Finance, 45, 157-174. http://dx.doi.org/10.1111/j.1540-6261.1990.tb05085.x

Baghestani, H. (1997). Purchasing power parity in the presence of foreign exchange black markets: the case of India. Applied Economics, 29, 1147-1154. http://dx.doi.org/10.1080/00036849700000005

Bahmani-Oskooee, M. (1988). Exchange Rate Flexibility and the Speed of Adjustment. Kyklos, 41, 35-49. http://dx.doi.org/10.1111/j.1467-6435.1988.tb02296.x

Bahmani-Oskooee, M. (1993). Black market exchange rates versus official exchange rates in testing purchasing power parity: an examination of the Iranian rial. Applied Economics, 25, 465-472. http://dx.doi.org/10.1080/00036849300000054

Bahmani-Oskooee, M. (1995a). Real and nominal effective exchange rate for 22 LDCS: 1971: 1-1990: 4. Applied Economics, 27, 591-604. http://dx.doi.org/10.1080/00036849500000048

Bahmani-Oskooee, M. (1995b). Real Effective Exhange Rates and the Purchasing Power Parity: Experiences of 19 Industrial Countries. Economic Notes, 24, 239-250.

Baillie, R. T., \& Sellover, D. (1987). Cointegration and Models of Exhange Rate Determination. International Journal of Forecasting, 3, 43-51. http://dx.doi.org/10.1016/0169-2070(87)90077-X

Beng, G. W. (1997). On the deviations from purchasing power parity: the case of the Ringgit effective exchange rate. Applied Economics, 23, 1461-1471. http://dx.doi.org/10.1080/00036849100000197

Cassel, G. (1916). The Present Situations of the Foreign Exchanges. The Economic Journal, XXVI, 319-323. http://dx.doi.org/10.2307/2221918

Cassel, G. (1917). The Depreciation of Gold. The Economic Journal, XXVII, 346-354. http://dx.doi.org/10.2307/2222293

Cassel, G. (1918). Abnormal Deviations in International Exchanges. The Economic Journal, XXVIII, 413-415. http://dx.doi.org/10.2307/2223329 
Corbae, D., \& Ouliaris, S. (1988). Cointegration and tests of purchasing power parity. Review of Economics and Statistics, 70, 508-521. http://dx.doi.org/10.2307/1926790

Davutyan, N., \& Pippenger, J. (1985). Purchasing power parity did not collapse during the 1970's. American Economic Review, 75, 1151-1158.

Dickey, D., \& Fuller, W. (1979). Distribution of the estimators for autoregressive time series with a unit root. Journal of the American Statistical Association, 74, 427-431.

Dickey, D., \& Fuller, W. (1981). Likelihood radio statistics for autoregressive time series with a unit root. Econometrica, 49, 1057-1072. http://dx.doi.org/10.2307/1912517

Dornbush, R. (1987). Purchasing power parity. In J. Eatwell, M. Migare, \& P. Newman (Eds.), The New Palgrave Dictionary. New York: Stockton Press.

Edison, H. J. (1987). Purchasing Power Parity in the Long Run: A Test of the Dollar/Pound Exchange Rate (1890-1978). Journal of Money, Credit and Banking, 19, 376-387. http://dx.doi.org/10.2307/1992083

Edison, H. J. et al. (1987). Understanding the empirical literature on purchasing power parity: the Post-Bretton Woods era. Journal of International Money and Finance, 16, 1-17. http://dx.doi.org/10.1016/S0261-5606(96)00046-0

Enders, W. (1988). ARIMA and cointegration tests of PPP under fixed and flexible exchange rate regimes. Review of Economics and Statistics, 70, 504-508. http://dx.doi.org/10.2307/1926789

Enders, W. (1995). Applied Econometric Time Series. John Wiley \& Sons.

Engel, R. F., \& Granger, C. W. J. (1987). Co-integration and error correction: representation, estimation and testing. Econometrica, 55, 251-276. http://dx.doi.org/10.2307/1913236

Fritsche, C. P., \& Wallace, M. (1997). Forecasting the exchange rate PPP versus a random walk. Economic Letters, 54, 69-74. http://dx.doi.org/10.1016/S0165-1765(96)00946-9

Froot, K. A., \& Rogoff, K. (1995). Perspectives on PPP and the Long-Run Real Exchange Rates. Handbook of International Economics, 3, 1647-1688. http://dx.doi.org/10.1016/S1573-4404(05)80012-7

Isaard, P. (1977). How Far Can We Push the "Law of One Price"? The American Economic Review, 67, 942-948.

Kim, Y. (1990). Purchasing Power Parity in the Long Run: A Cointegration Approach. Journal of Money,Credit and Banking, 22, 491-503. http://dx.doi.org/10.2307/1992433

McNown, R., \& Wallace, M. S. (1989). National price levels, purchasing power parity, and cointegration: a test of four high inflation economies. Journal of International Money and Finance, 8, 533-545. http://dx.doi.org/10.1016/0261-5606(89)90035-1

McNown, R., \& Wallace, M. S. (1990). Cointegration test of purchasing power parity among four industrial countries: results for fixed and flexible rates. Applied Economics, 22, 1729-1737. http://dx.doi.org/10.1080/00036849000000078

McNown, R., \& Wallace, M. S. (1994). Cointegration Tests of the Monetary Exchange Rate Model for Three High-Inflation Economics. Journal of Money Credit, and Banking, 26, 396-410. http://dx.doi.org/10.2307/2078009

Murray, M. P. (1994). A Drunk And Her Dog: An Illustration of Cointegration and Error Correction. American Statistical Association, 48, 87-89.

Phylaktis, K. (1992). Purchasing power parity and cointegration: the Greek evidence from the 1920's. Journal of International Money and Finance, 11, 502-513. http://dx.doi.org/10.1016/0261-5606(92)90015-P

Pindyck, R. S., \& Rubenfeld, D. L. (1991). Econometric Models and Economic Forecasts. McGraw Hill.

Rogoff, K. (1996). The Purchasing Power Parity Puzzle. Journal of Economic Literature, XXXIV, 647-668.

Taylor, M. P. (1988). An empirical examination of long-run purchasing power parity using cointegration techniques. Applied Economics, 20, 1369-1381. http://dx.doi.org/10.1080/00036848800000107

Taylor, M. P. (1995). The Economics of Exchange Rates. Journal of Economic Literature, XXXIII, 13-47.

Yeager, L. B. (1958). A Rehabilitation of Purchasing Power Parity. Journal of Political Economy, LXVI, 516-530. http://dx.doi.org/10.1086/258103

Zhou, S. (1994). Purchasing Power Parity in High-Inflation Countries: Further Evidence. Journal of 
Macroeconomics, 16, 403-422. http://dx.doi.org/10.1016/0164-0704(94)90014-0

Zhou, S., \& Mahdavi, S. (1997). Purchasing Power Parity in High-Inflation Countries: A Cointegration Analysis of Integrated Variables with Trend Breaks. Southern Economic Journal, 64, 450-467. http://dx.doi.org/10.2307/1060860

\section{Copyrights}

Copyright for this article is retained by the author(s), with first publication rights granted to the journal.

This is an open-access article distributed under the terms and conditions of the Creative Commons Attribution license (http://creativecommons.org/licenses/by/3.0/). 